\title{
Nearing 125 Years of ASEE
}

\author{
Catherine Skokan ${ }^{1}$ \\ ${ }^{1}$ American Society for Engineering Education, 1818 N Street, NW, Suite 600, Washington, \\ DC, USA 20036, cskokan@mines.
}

\begin{abstract}
The American Society for Engineering Education began in 1893 as the Society for the Promotion of Engineering Education. From the 70 charter members, the membership has grown to over 400 academic institutions, 50 corporations, and 11,660 individuals. ASEE is dedicated to furthering engineering education through excellence in teaching and research throughout the United States and internationally. To this end, ASEE has worked closely with Japan in establishing JSEE. Today, ASEE values its partnership through a Memorandum of Understanding with JSEE and looks forward to continued communication and cooperation.
\end{abstract}

\section{Keywords: Engineering Education, ASEE, JSEE, history}

\section{The Early Years}

In the late 1800's civil and mechanical engineering societies came together to discuss academic preparation of engineers [1,2,3]. At the 1893 World's Columbian Exposition (World's Fair) in Chicago, a group organized a special session of the Engineering Congress. The final result was the formation of the Society for the Promotion of Engineering Education (SPEE). The leaders of this new organization promoted the concept that engineering education should include scientific and mathematical fundamentals instead of apprenticeships. By the second year, the membership had more than doubled from a charter membership of 70 to 156 members. By 1905, the membership had grown to 400 individuals and 85 institutions. In 1910, a monthly Bulletin was first published to keep members apprised of Society news. SPEE became recognized as the voice of engineering education across disciplines.

In the pursuit of engineering education excellence, the first of many studies was undertaken in $1907 . \quad$ The resulting Mann Report presented in 1918 made numerous recommendations [1,2,3]. These included a recommendation for a common core for all engineers emphasizing theoretical science and mathematics as well as practical industrial applications. The report also urged dropping foreign language requirements. Surveys indicated that many felt that success in engineering fields was a matter of character. Mann's committee suggested psychological testing of candidates for admissions and improving retention. For SPEE, the Mann Report confirmed that the study of engineering education was a critical activity.

The next major project, the Wickenden Study [1,2,3], of engineering education involved data collection from 150 engineering schools and over 700 faculty members. The data included information on curricula, faculty, students, and graduates. Data collection and analysis spanned from 1923 -1930. The Wickenden Study commented on engineering curriculum saying that a program of more than four years was unrealistic and encouraging a strengthened liberal arts component. Two other recommendations were for a summer workshops for engineering faculty and for accreditation of engineering schools. Both were put into action.

Because of the volunteer structure of SPEE at that time and the expense involved, the society did not create an accreditation system. Instead, a new group, Engineers' Council for Professional Development (ECPD) was formed in 1932 and began accrediting engineering programs [4]. In 1980, the name of this group was changed to Accreditation Board for Engineering and Technology (ABET).

\section{Transition to the American Society for Engineering Education}

During World War II, the federal government had an increased interest in engineering research and education. Funding of research projects changed the face of engineering programs in universities. A new organization, the Engineering College Research Association (ECRA) was formed in 1942 to address this issue. At the same time, the Division of Deans and Administrative Officers of SPEE wanted a stronger voice and considered forming a separate organization. In response to these splintering efforts, a reorganization of SPEE began in 1945. In 1946 , the reorganized society approved a new name: American Society for Engineering Education (ASEE) [1].

Under its new name, ASEE began another study of engineering education starting in 1952 [1,2,3]. Led by L. E. Grinter, the study committee initially made three recommendations. The first recommendation included a strengthening of liberal arts in engineering education and graduate studies. This resulted in the formation of additional studies on these topics. The second recommendation addressed more use of scientific and mathematical principles. 
The third recommendation was to recognize two tracks of engineering education: an undergraduate only program to prepare student for industry and a research-oriented graduate program. The third recommendation was received unenthusiastically, but overall, the Grinter Report did result in a greater emphasis on scientific and mathematical fundamentals in engineering education. ASEE continues to investigate directions in engineering education with periodic reviews and reports. The Walker Report of 1965 reiterated much of what earlier reports had suggested. The most recent study (2012) resulted in a report "Innovation with Impact" [3].

\section{Engineering Education Mission to Japan}

In 1951, a mission consisting of fifteen representatives from ASEE, visited Japan for "exchange of Ideas with Japanese engineering educators" [5]. The outcome of this mission was a set of recommendations:

1. Each university should be autonomous with respect to program development paying attention to local strengths.

2. Each university should remain flexible to be able to respond quickly to changing needs and environment.

3. Both teaching and research should function jointly and be equally valued.

4. A close relationship between faculty and students should be fostered.

5. Exchange between students and faculty from various institutions should be encouraged to guard against inbreeding.

6. Engineering Technology programs is vital and a component of the overall engineering education effort.

7. Close relationships between academia and industry should be cultivated.

8. Quality engineering education is costly. "Find the money."

9. Four-year engineering programs should be augmented with graduate opportunities.

10. An engineering education society should be established (JSEE).

11. Libraries should be strengthened.

12. Wider use of textbooks and classroom discussions of homework assignments was recommended.

13. The national tax system should be restructured to encourage donations to engineering institutions.

In partial response to these recommendations, JSEE was established in 1952 [6]. Then, in 1963, JSEE became a member of ASEE. A Memorandum of Understanding (MOU) was signed with ASEE in 1993 and our organizations continue to operate under this same MOU. ASEE values this cooperation with JSEE.

\section{Recent Programs}

Engineering education has transformed recently to contain topics of environmental and social concerns and, also, to include a move diverse community into the engineering profession. Accreditation programs now encourage individuality in institutions to respond to local needs and interests. In a seeming contradiction, engineering education has shifted to involve more global perspectives and awareness of global economy. Showing a strong future for research in engineering education, Christensen, et al. [7] suggest: "More empirical research on the institutional contexts of engineering education with respect to ongoing transformations both local and globally will be a priority".

ASEE continues to work in the arena of excellence in engineering and technology education. The organization has a sustained interest in innovation of classroom practices and curriculum; promotion of faculty development; cooperation between governmental, corporate, industrial, and academic institutions; and promotion the value of the engineering profession for society. Some of the most recent efforts include:

1. Awareness of the needs for contributions from a diverse membership [8].

2. Involvement in establishing P-12 engineering standards.

3. Encouraging cooperation with research engineering institutions with non-PhD granting institutions.

4. Increasing representation of women and underserved minority faculty.

Communication with the membership to accomplish these efforts include a national convention, regional conferences, workshops, an international forum, a website, and journals. ASEE had three major publications. Journal of Engineering Education (JEE) has been published under several names since 1893. Today, the emphasis of this journal is research in engineering education. PRISM is the bi-monthly publication that reports the latest technology and trends. The newest journal, Advances in Engineering Education (AEE), publishes papers dealing with innovative classroom practices.

In addition to the direct membership services, ASEE is externally funded to carry out over 20 grants and projects from sponsoring agencies that range from governmental to private [9]. These agencies include the Department of Defense, Naval Research Laboratory, National Science Foundation, Department of Labor, Intel Foundation and the Association of Colleges and Universities. The grants and projects cover topics of administration of fellowships, scholarships, and internships; data collection and analysis; research and meeting logistical support; and student engagement. These grants and project are aimed at the mission of ASEE and are of benefit to the membership as well as the engineering profession. 
The ASEE vision statement [3] provides an excellent summary of the organization: " ASEE will serve as the premier multidisciplinary society for individuals and organizations committed to advancing excellence in all aspects of engineering and engineering technology education."

\section{Conclusion}

Since its founding nearly 125 years ago, ASEE has served as the voice for education across all engineering disciplines and as a platform for improvement of educational instruction for engineers. Membership has grown to over 400 academic institutions, 50 corporations, and 11.660 individuals [10]. For these members, ASEE provides a vehicle for communication among those interested in education and the engineering profession. In today's interconnected world, ASEE values international partners. JSEE is one of the longest term and significant partnerships.

The ASEE website [3] summarizes the importance of international outreach. "ASEE seeks to facilitate productive global collaborations among industry, academe, and government and to increase participation in its activities to more completely serve the engineering and engineering technology enterprise. International cooperation in matters pertaining to engineering education is particularly crucial to the U.S. engineering community as it endeavors to enhance its capacity to attract and retain highly-skilled engineering professionals, to advance research in engineering education, and to foster collaboration between scholars and practitioners".

\section{References}

1. Reynolds, Terry and Seely, Bruce, Striving for Balance: One Hundred Years of the Society for Engineering Education, Jour. Eng. Ed., Vol. 82, No. 3, p. 136-151, 1993.

2. ASEE, ASEE at 120-1-10-13, unpublished report, 2013.

3. ASEE web site: https://www.asee.org/, accessed June 2016.

4. ABET web site: http://www.abet.org/about-abet/history/, accessed June 2016.

5. Hazen, Harold, Report of the Engineering Education Mission, unpublished report on file in ASEE permanent records, 1951. ASEE web site: https://www.asee.org/, accessed June 2016.

6. JSEE web site: https://www.jsee.or.jp/English/About-Us/, accessed June 2016.

7. Christensen, Steen, et. al. (eds.), International Perspectives on Engineering Education: Engineering Education and Practice in Context, Vol.1, Springer International Publishing Switzerland, 2015.

8. ASEE, '15 Annual Report - A Year of Action on Diversity, unpublished report, 2016

9. ASEE, Project Board Summary Report, unpublished report, June 2016.

10. ASEE, Annual Membership Report, unpublished report, 2016.

\section{Biography}

Catherine Skokan graduated from the Colorado School of Mines with BS, MS, and PhD in Geophysical Engineering. As a faculty member at Mines, her research topics included geophysical studies in the areas of geothermal, volcanic, and groundwater issues. As a PI or CoPI, she worked on twenty research projects in the arena of engineering education. She is active in professional societies for both geophysics and engineering education. She is the past president of the Engineering and Environmental Geophysics Society and has served on the boards for the Colorado Association of Science Teachers and the American Society for Engineering Education. She currently serves as Vice President of External Affairs at ASEE. Presently, Dr. Skokan is retired but stays very busy in ASEE activities as well as teaching short courses and workshops for teachers or students, and traveling. She believes that international experiences are essential for every engineer's education and often travels with CSM students. 